RJPSS Sept. 2020 Vol. XLV No.2, ISSN: (P)0258-1701 (e)2454-3403 Impact Factor: 7.717

https://doi.org/10.31995/rjpss.2020.v45i01.032

\title{
Education 4.0: The Blueprint to Re-Define Learning in the Post COVID 19 World
}

\author{
Asha Gour \\ Assistant Teacher \\ Department of Education \\ Dept. of Basic Education, Saharanpur \\ Email:gour.asha1@gmail.com
}

\begin{abstract}
The advent of COVID 19 has altered the way we would live in the coming years and its impact is potentially being realized in every sector. As the world grapples to fight against this global malady, the Education sector has altered this challenge into an opportunity, by harnessing the benefits of new-age technologies such as Internet of Things (IoT) and Artificial Intelligence (AI).

The new blueprint of education, popularly touted as: Education: 4.0 or new-age learning is inclined towards creating a paradigm shift in the Indian Education system, wherein schools, colleges, institutions of higher learning and universities are reimagining the learning processes and implementing tools to create classrooms of the future.

The outbreak of Coronavirus has made us realize that the education is not restricted to classrooms anymore. India being a population of millennial has further catapulted the notion of re-imagining classrooms in a virtual mode by harnessing the power of internet more effectively. The institutions of learning on the other hand are making an optimum use of highest quality technology to create a thriving academic atmosphere for the students.

E-Learning platforms have rather intensified the process of learning despite restrictions bought by the novel virus outbreak and offer teachers and students with not just plethora of disciplinesto choose from but come hard packed with methodologies that are easy to grasp and easier to understand. Leading educators in India believe that using a mix of traditional methods with the new online developed tools is the key to success: The pathway to new-age education.
\end{abstract}

Reference to this paper should be made as follows.

Received: 28.07.2020

Approved: 30.09.2020

Asha Gour

Education 4.0: The

blueprint to Re-Define Learning in the Post COVID 19 World

Article No. 32

RJPSS Sept. 2020,

Vol. XLV No. 2, pp. 267-274

Online available at: https://anubooks.com/ ripss-2020-vol-xlv-no-2/

https://doi.org/10.31995/ rjpss.2020.v45i01.032 
Education 4.0: The Blueprint to Re-Define Learning in the Post COVID 19 World

Asha Gaur

\section{Objective:}

The objective of the research is to analyze the growing impact of COVID 19 on the education sector and what is the way forward for the Indian education system. How universities and institutes of higher learning are following the footprints of new-age technologies to provide a boost to the learning and create a paradigm shift by bringing in cutting-edge technologies to abstain from traditional methods of Blackboard teaching.

The research further sheds light on popular tools of online-education in India and how far are they accessible for the students in remote areas where the connectivity via internet is just a dream waiting to furbish .Lastly, the research tends to share insights on the need to fill Skill Vs Demand gap and the challenges for the teachers to be equipped with right resources to conduct classes online, in a virtual mode.

\section{Introduction:}

In March this year, India witnessed grim realities of the novel coronavirus, as the number of cases in the country intensified to bring a major halt in every possible human activity. The lockdown effected every sector and Education at large didn't remained untouched. Theresponsibility of protecting children and students from the virus was much potent and the government announced an unplanned lockdown down on schools, colleges, universities and institutions of higher learning. According to a study done by World Economic Forum, globally around 1.2 billion children were forced to stay out of the classroom.

The United Nations Educational, Scientific and Cultural Organization (UNESCO), claimed over 157 crore enrolled students across the world are impacted by severe disruption in their education because of the COVID-19 pandemic. It has emerged as the single biggest challenge that the modern world has faced in many decades.

According to educators and researchers, online education is expected to grow from $\$ 247$ million in 2016 to $\$ 1.96$ billion by 2021 . The importance of virtual learning is increasing as the academic year has been drastically interrupted due to Covid-19. The students are left with no other choice rather than attending classes online.

Research also suggests that online learning has been shown to increase retention of information, and take less time, meaning the changes coronavirus have caused might be here to stay. Whether it is language apps, virtual tutoring, video 
conferencing tools, or online learning software, there has been a significant surge in usage since COVID-19.

While many believe even before COVID-19, there was already high growth and adoption in education technology, with global edtech investments reaching US\$18.66 billion in 2019 and the overall market for online education projected to reach $\$ 350$ Billion by 2025 , the sector is also witnessing challenges in implementing the E-learning model as a way forward in the future of the education.

The 2020-21 Union Budget present by Indian government, allocated ${ }^{1} 15$ Crore less to teacher training as compared to last year. Citing, there is a growing need of trained workforce that is compatible with using new-age tools of learning to impart education to the students, theallocation of fund by the government is far much less.

Despite brining in a new-age revolution in education, we cannot expect a fundamental change in the sector unless our teachers are prepared for it.

\section{COVID-19's Staggering Impact On Global Education}

Number of learners impacted by national school closures worldwide

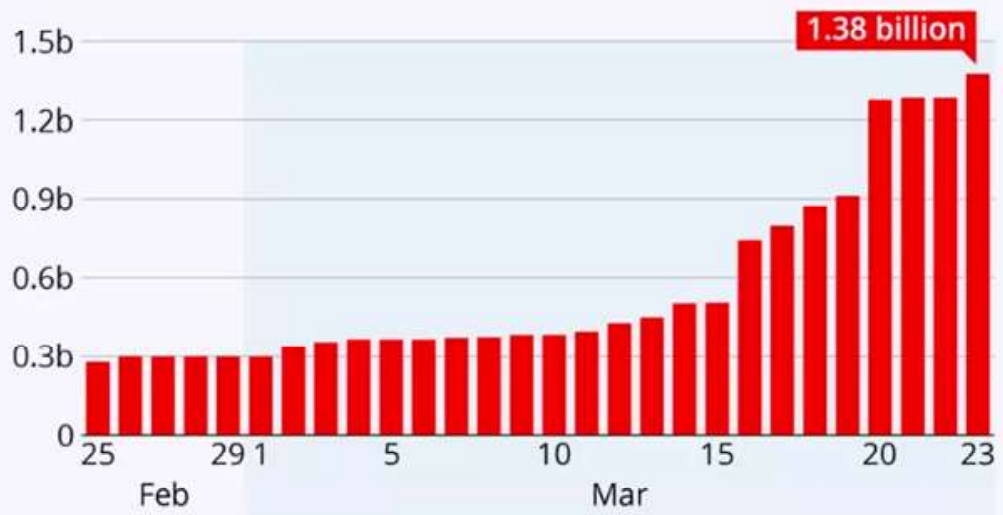

Figures refer to learners enrolled at pre-primary, primary, lower-secondary, and upper-secondary levels of education, as well as at tertiary education levels. Source: UNESCO

Exhibit 1: The staggering impact of COVID 19 on Global Education 
As per a report by BARC India and Nielsen, there has been a 30\% increase in the time spent on education apps on smartphones since the lockdown. Ed-tech platforms are working with schools and colleges to develop ways in which teachers can come on board and use tools to impart learning. India's edutech market is projected to be worth $\$ 2$ billion ( $£ 1.5$ billion) by 2021, based on 9.6 million users, according to a 2016 report by KPMG and Google.

As we move to a greater proliferation of devices, combined with the fact that we will be accessing more content from multiple places, a greater value will be placed on the content, and how that content is used. It is no secret that visual input greatly enhances the learning capacity of students. Ed tech platforms are now innovating new possibilities in this uncharted territory of social and group learning to enable education beyond the boundaries of a school.

Exhihit 2: The exsentials to hridoe. Skill Vs. Demand Gan for F-Iearnino:
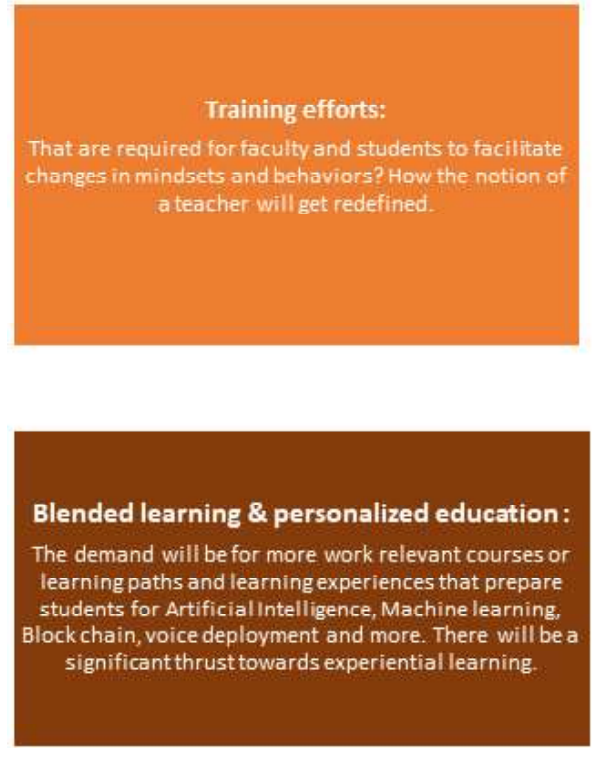
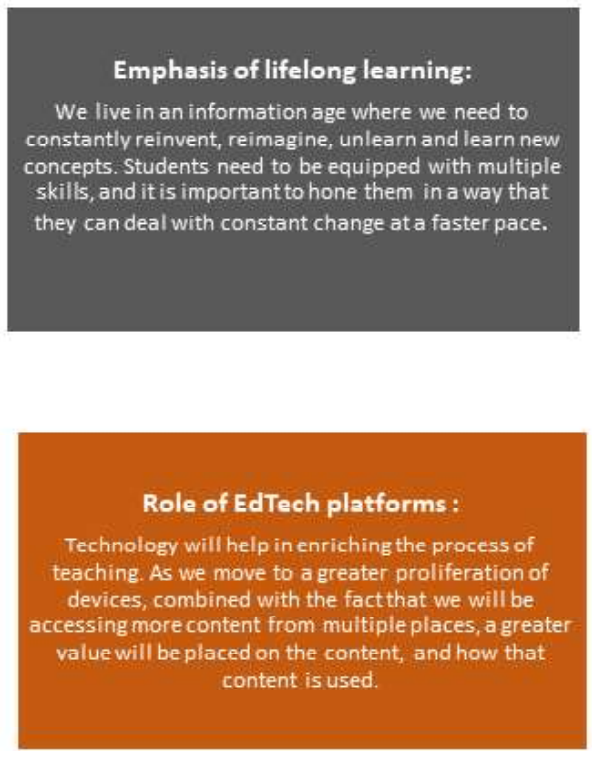

\section{Leading Ed-Tech platforms for New-Age Learning:}

It is needless to say, that India needs to re-imagine the learning processes by creating a more engaging and inculcating platform for learning on the internet. As per educators, the need to re-imagine learning is critical to the overall development of the students and their success in the longer run. The future is bound by the advent of new technologies like Artificial Intelligence(AI) and Internet of Things(IOT) 
RJPSS Sept. 2020 Vol. XLV No.2, ISSN: (P)0258-1701 (e)2454-3403 Impact Factor: 7.717

https://doi.org/10.31995/rjpss.2020.v45i01.032

and one can't afford to not excel in these new genres of internet development. In the post COVID 19 era, the industries across sectors will be looking forward to a much skilled workforce that is proficient in the field of new age technologies. And the time to strengthen the roots of such a new world is just now.

In response to the growing demand, many online learning platforms are offering a free access to their services, including India's leading ed-tech company BYJUS, Gradeup, upGrad, Topper among others.

Since announcing free live classes on its Think and Learn app, BYJU's has seen a $200 \%$ increase in the number of new students using its product, according to Mrinal Mohit, the company's Chief Operating Officer.

Globally, Tencent classroom is being used extensively since mid-February after the Chinese government instructed a quarter of a billion full-time students to resume their studies through online platforms. This resulted in the largest "online movement" in the history of education with approximately 730,000 , or $81 \%$ of K12 students, attending classes via the Tencent K-12 Online School in Wuhan.

In India, companies are bolstering their efforts to provide a one-stop-shop solution to teachers and students to continue with their teaching and learning without any halt.

\section{The rise of Ed-Tech industry amid COVID 19:}

In the light of new developments happening under the influence of Coronavirus, several Ed-Tech startups in India came up with the decisions that positively impacted the education sector at large. An unprecedented traffic was witnessed on these websites amid the announcements to conduct online classes for free and provide students with access to relevant study material for their entrance exams preparation, online learning etc.

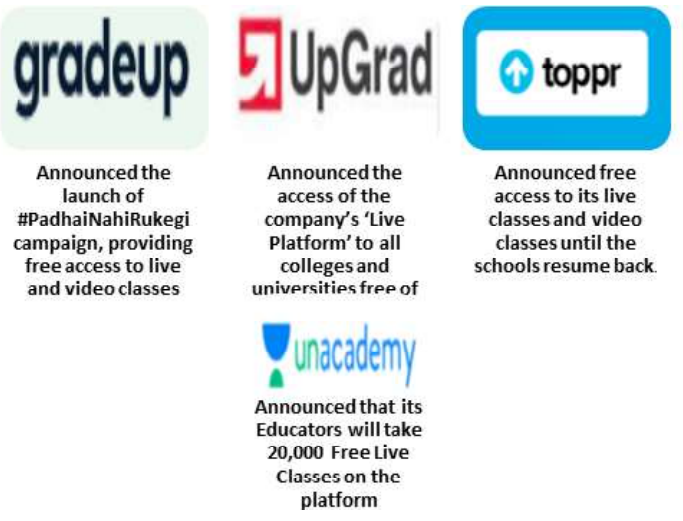


Education 4.0: The Blueprint to Re-Define Learning in the Post COVID 19 World

Asha Gaur

\section{A short synopsis of what Ed-Tech Industry spoke of COVID 19:}

"Schools and colleges in many cities in India too have been asked to shut down. To minimize the effects of this disruption, we have opened up our live platform to educational institutions and universities free of cost," said Ronnie Screwvala, executive chairman and co-founder, upGrad.

"There has been a 50\% growth in subscribers of Live Classes month on month along with $30 \%$ growth in traffic. As we iterate on various GTM options in the given situations, our estimated 5xincrease in paid subscribers in the medium term," said Zishaan Hayath, chief executive officer and co-founder, Toppr.

"We have seen a 20-25\% increase in daily enrolments already, especially in live classes. The spike is across all segments, but especially true for JEE and NEET aspirants with their exams being postponed. The growth rate varies from $25 \%$ to $40 \%$ across segments," said Shobhit Bhatnagar, chief executive officer and cofounder, Gradeup.

"We are bringing together our entire network of Educators to conduct Free Live Classes for learners across the nation to help them crack their goals unobstructed. We want learners to utilize this time to take precautions against the coronavirus outbreak and learn from the comfort of their homes. We will support the education system in every way possible to weather the storm and provide these classes to each learner who wants to utilise Unacademy to study. If the situation persists beyond March, we will look at extending these Free Live classes to April and May as well," said Gaurav Munjal, Co-Founder and CEO, Unacademy.

Disclaimer: The testimonies have been compiled from the media reportage post COVID 19.

\section{Emerging tools of new-age learning: A hybrid form of Education}

Gone are days, when traditional learning focused on pedagogy was used to impart education and remained restricted within the boundaries of a classroom. Today, it is an era of online education that focuses upon a richer hybrid form of education that incorporates the use of different tools to maximize the understanding of the students and enable them to be proficient in their subjects. The features of online learning includes: interactive videos, one-on-one interactions with the subject matter expert over video chatting platforms, and instant sharing of essential information to a large group of people.

The universities and institutions of higher learning are harnessing the use of popular platforms like Coursera, Blackboard Collaborate and Zoom to ensure a smooth and engaging learning experience for the students. 


\section{coursera}

\section{Blackboard}

\section{Zoom}

Founded by Daphne Koller and Andrew Ng with a vision of providing life-transforming learning experiences to anyone, anywhere. It is now a leading online learning platform for higher education, where 62 million learners from around the world come to learn skills of the future. More than 200 of the world's top universities and industry educators partner with Coursera to offer courses, Specializations, certificates, and degree

A simple and reliable virtual classroom solution to empower online teaching and web conferencing needs. Gives the students more options to stay engaged - with

collaborative learning tools for their mobileenabled lives. Provides Creative mobile-

friendly flipped lessons that don't disappear after two weeks.

Zoom helps businesses and organizations bring their teams together in a frictionless environment to get more done. It is easy, reliable cloud platform for video, voice, content sharing, and chat runs across mobile devices, desktops, telephones, and room systems. Zoom is publicly traded on Nasdaq

(ZM) and headquartered in San Jose, California.

\section{Conclusion:}

- It is clear that the pandemic has opened a new window to imparting education in the form of E-learning and has utterly disrupted the traditional mode of learning, that many already believed was redundant 
- Critical Thinking and adaptability are important for the growth of children and the adaption of E-Learning has escalated the value and importance of these qualities for the students

- Online learning is bound to stay and will serve as a catalyst in advancing the modes of education in a new-age world

- E-Learning will also be critical for bridging the Skill Vs Demand gap that the industries face today as students will be more proficient in creating things rather than focusing on the rotten theoretical education approach.

\section{Needs /Suggestions for E-Learning:}

- The lack of reliable internet access in the remote areas halts the process of learning for the students. The govt. of India needs to ensure that students especially in these areas are able to harness the benefits of E-Learning by providing them with necessary resources and equipment

- A significant gap between the students from the privileged and disadvantaged backgrounds leads to a difference in having an equal access to E-Learning. Therefore, the institutions of learning need to develop and further strengthen their resources to provide direct benefit to the students despite status

- The lack of resources with government schools and training for the teachers along with required equipment raises concerns that the pandemic will widen the digital divide. The government should make sure that the teachers are skilled and well equipped to impart education online

- There is still a growing need of structured environment, especially for the growing children to learn online. To get the full benefit of online learning, there needs to be a concerted effort to provide this structure and go beyond replicating a physical class/lecture through video capabilities, instead, using a range of collaboration tools and engagement methods that promote "inclusion, personalization and intelligence

\section{REFERENCES}

1. Research by UNCESO and WEF on the impact of COVID 19 on education globally

2. Media reportage basis the outlook of E-Learning and its growing impact in India amid COVID 19 